16. Haug R. H., Schwimmer A. Fibrous union of the mandible: A review of 27 patients. J. Oral Maxillofac Surg. 1994. Vol. 52. P. 832-839.

17. Idashkina N. Five Years Retrospective Study of Mandibular Fractures in Mechnikov Regional Clinical Hospital, Dnipropetrovsk. Eur. J. Biomedical and Life Sciences. 2018. N 3. P. 3-6.

18. Influence of perioperative dexamethasone on delayed union in mandibular fractures: a clinical and radiological study / Snäll J. et al. Med. Oral. Patol. Oral. Cir. Bucal. 2015. Vol. 20. P. e621-6.

19. Nonunion of mandible : an analysis of contributing factors / Mathog R. H. et al. J. Oral. Maxillofac. Surg. 2000. Jul. (Vol. 58, N 7). P. 746-753.

20. Nakamura Seiji, Takanoshita Yashura, Masuichiro. Complications of miniplate osteosynthesis for Mandibular fracture. J. Oral Maxillofacial Surgery. 1994. Vol. 52. P. 233-238.

The article was received 2019.01.28

\title{
R.E. Vasilenko \\ STATISTICAL ANALYSIS OF REPAIR OF COMPLETE REMOVABLE DENTURES ON THE UPPER JAW FOR A THREE-YEAR PERIOD OF USE
}

SE «Dnipropetrovsk medical academy of Health Ministry of Ukraine»

Department of Prosthetic Dentistry

D. Yavornytskyi, 24, Dnipro, 49044, Ukraine

e-mail:denta@ua.fm

Д3 «Дніпропетровська медична академія МОЗ Украӥни»

кафедра ортопедичної стоматологіi

(зав. - д. мед. н., проф. О.О. Фастовеиь)

пр. Д. Яворнииького, 24, Дніпро, 490044, Україна

\section{Цитування: Медичні перспективи. 2019. Т. 24, № 1. С. 61-65}

Cited: Medicni perspektivi. 2019;24(1):61-65

Key words: maxilla, complete adentia, complete removable denture, base, denture repaire, life time Ключові слова: верхня щелепа, повна адентія, повний знімний протез, базис, лагодженння протеза, термін користування

Ключевые слова: верхняя челюсть, полная адентия, полный съемный протез, базис, лагодженння протеза, срок пользования

Abstract. Statistical analysis of repair of complete removable dentures on the upper jaw for a three-year period of use. Vasilenko R.E. The aim of the study is to analyze the use of full dentures on the upper jaw and the number of repeated visits of patients who received treatment at the dental offices in the Dnepr city. Materials and methods: 
during 2015-2017 years in dental office of the SE "DMA", patients were examined, a statistical analysis was made, the number of manufactured of full dentures on the upper jaw and, accordingly, the number of repairs for each year and comparison statistics with the city dental clinics in the previous years was done. According to the results of the study, it was established then in three-year examination period the patients in three dental clinics of the city, the percentage of breakdowns and correction of full dentures on the upper jaw was near 50\%. At dental office of SE "DMA", according to the results 2015-2017 years a number of 48.4\% was obtained. So that when we compared with the dental clinic from the previous study that is closest in scope of the work, it indicates the absence of statistically significant differences in the indicators of the first and second studies. This can be explained by the fact that despite the use of more modern materials and methods in the manufacture of complete dentures, the problem of improving the quality of full dentures manufacturing on the upper jaw and increasing the strength of the base has not been fully resolved.

Реферат. Статистический анализ ремонтов полных съемных протезов верхней челюсти за трехлетний период использования. Василенко Р.Э. Цель исследования - анализ пользования полныли съемными пластиночными протезами (ПСПП) на верхнюю челюсть и количества повторных обращений пациентов, получавщих помощь на базе стоматологических отделений г. Днепра. Материаль и методы: обследованы пациенты на базе клиники ГУ «ДМА» на протяжении 2015-2017 г2., проведен статистический анализ количества изготовленных полных съемных протезов на верхнюю челюсть и соответственно количества починок за каждый год. Проведено сравнение статистических данных 3-х стоматологических поликлиник города в предылущие годы. По результатам скрининг- исследования пациентов 3-х поликлиник города в предыдущие годы средний процент поломок и коррекиий полных съемных пластиночных протезов на верхнюю челюсть 8 среднем приближен к 50\%. На базе клиники ГУ "ДМА" по результатам исследования получено число в 48,4\%, что при сопоставлении с наиболее близкой по объему выполненных работ поликлиникой из предыдущего исследования указывает на отсутствие статистически значимых отличий показателей первого и второго исследований. Это может объясняться тем, что, несмотря на применение более современных материалов и методов при изготовлении базисов ПСПП, проблема улучшения качества изготовления ПСПП на верхнюю челюсть и повышения прочности базиса до конца не решена.

Presently in Ukraine a lot of elderly people experience a complete absence of teeth. The percentage of such people aged $60-69$ is $9.9 \%$, at the age of $70-79$ years - up to $29.0 \%$, over $80-89$ years $40.2 \%$ and it attains a maximum in the group above 90 years $-78.4 \%$ [3]. Despite the rapid development of dental implantology, complete removable prosthesis remains the most common type of orthopedic dental care, and 58 people per 1,000 are in need for it [4]. The most often acrylic plastics are used in the manufacture of complete removable dentures bases - in $98.0 \%$ of cases [1]. Despite the fact that this kind of dental materials is quite popular in dentures, it has a number of shortcomings, one of which is insufficient strength. According to the generalized data of various statistical analyses, the number of damages and remodeling of complete removable dentures, made of modern acrylic base materials in the first year of usage is from 3 to $14,2 \%$, over a 3 year period of dispensary follow-up it is about $50 \%$. The literature data [5] show that most of the cases of damages and cracks in the base of the complete removable laminar dentures (CRLD) of the upper jaw $-52.4 \%$ are those that began between the central and lateral incisors, further along the projection of the palatine suture, with the ending in the distal part of the denture. In the next group of frequency, the fracture line began between the canine tooth and the first premolar $-47.5 \%$ of cases, distributing almost equally between the right and left side and ending at a distance of $0.2-0.8 \mathrm{~cm}$ from the median line of the base of the complete removable denture of the upper jaw.

The purpose of the study was to analyze the use of complete removable laminar dentures on the upper jaw and the number of repeated visits of patients who received treatment at the dental offices in Dnipro city.

\section{MATERIALS AND METHODS OF RESEARCH}

In order to objectify the data on the state of the CRLD of the upper jaw during their usage, we carried out two screening investigations covering a 3-4 year period of dispensary follow-up of patients with CRLD.

The first study was conducted among patients on the basis of three orthopedic departments of the dental institutions of Dnipro: CI "Regional Dental Clinic", CI "City Dental Clinic N 1", CI "City Dental Clinic N 2" during 2007-2010. The second one among 540 patients who received treatment in the dental clinic of SE "Dnipropetrovsk Medical Academy of Health Ministry of Ukraine." in 2015-2017.

The statistical processing of the study results was carried out using statistical software package Statistica version $6.1^{\circledR}$. Data are presented as mean and standard error $(\mathrm{M} \pm \mathrm{m})$. The reliability of the differences was evaluated in paired comparisons by Mann-Whitney (U) criterion, with multiple comparisons of 3 groups - according to the Kruskall-Wallis criterion $(\mathrm{H})$. 


\section{RESULTS AND DISCUSSION}

According to the results of the first study conducted in 2007-2010, data were obtained on the number of manufactured and repaired CRLDs during this period (Fig. 1).

The calculation of the specific gravity of the repair of CRLDs of the upper jaw among established dentures showed that the proportion of additional interventions of the orthopedist or dental technician exceeds $50 \%$ and does not significantly depend on the medical institution, especially with large volumes of work (Fig. 2).

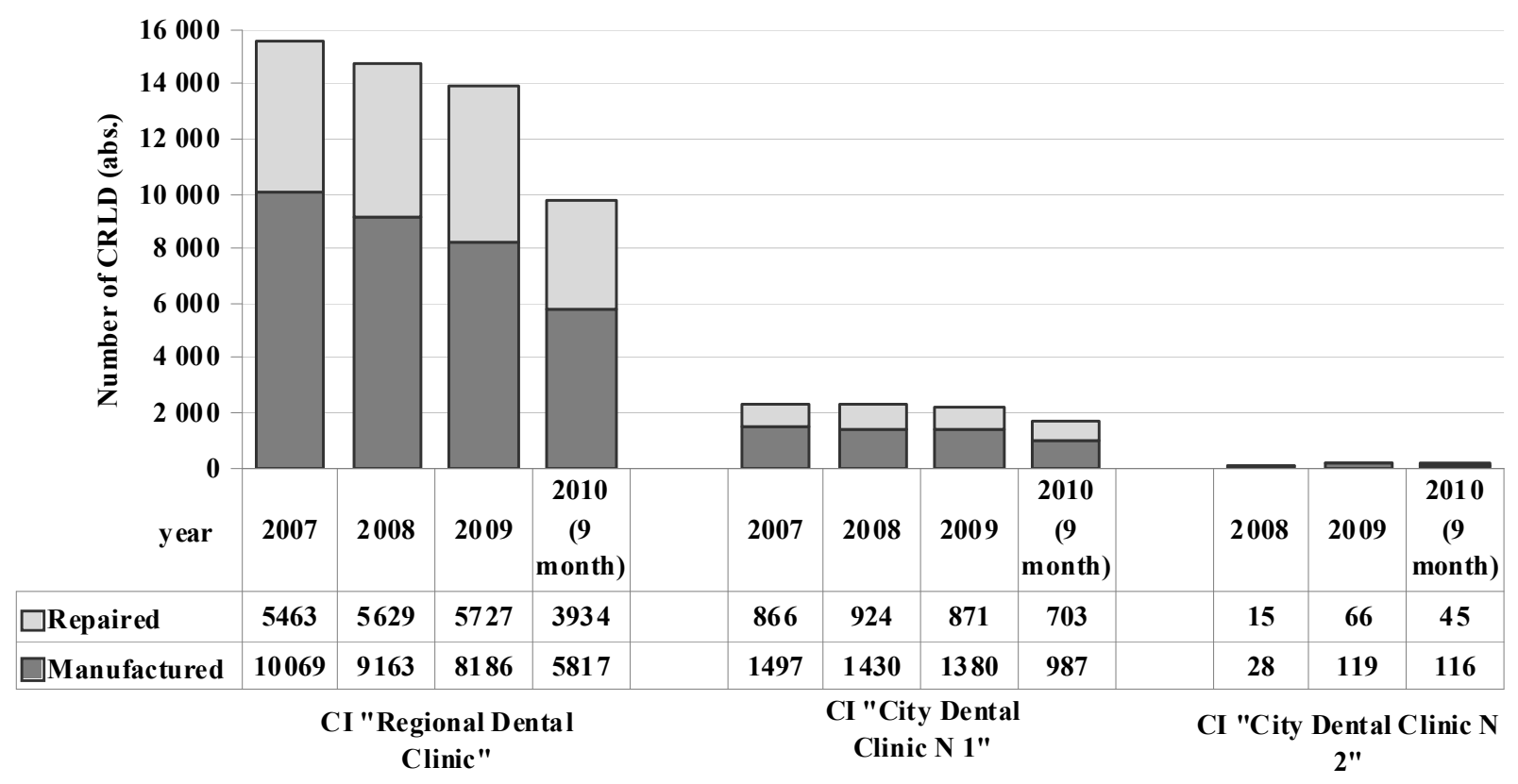

Fig. 1. The total number of manufactured and repaired CRLDs in 2007-2010 on the basis of orthopedic departments of the dental institutions of Dnipro

Thus, the average index of the relative number of repaired CRLDs in the CI "Regional Dental Clinic" was $63.3 \pm 3.5 \%$ annually, in the CI "City Dental Clinic N 1" - 64.2 $\pm 2.8 \%$ ( $\mathrm{p}=1.0$ according to criterion $\mathrm{H}$ ), in the CI "City Dental Clinic N 2" $49.3 \pm 5.3 \% \quad(p=0.196$ and $p=0.097$ in comparison with the previous groups according to criterion $\mathrm{H}$ ).

In order to compare the current trends in the quality of the manufacture of CRLD with past years, a study was conducted on the basis of the clinic of SE "DMA HM of Ukraine during 2015-2017. The obtained data also indicate a high percentage of the number of repairs of CRLD of the upper jaw $48.4 \pm 0.6 \%$ (tabl.).

A comparative analysis of the data on a relative number of CRLDs repair for both periods of observation conducted between the medical institutions CI "City Dental Clinic N 2" and the clinic of the SE "DMA HM of Ukraine", taking into account the same volumes of work, showed a lack of statistically significant differences between the mean indicators for a three-year period of observation $-49.3 \pm 5.3 \%$ versus $48.4 \pm 0.6 \%$ ( $\mathrm{p}=0.513$ according to criterion $U$ ).

Thus, based on the findings of the first study, it can be concluded that more than $50 \%$ of CRLD on the maxilla during three years of operation require the intrusion of an orthopedist or dental technician. This indicates a high number of repeated visits due to fractures, cracks and remodeling of the bases of CRLD of the upper jaw. Among the reasons that cause this phenomenon is the unsatisfactory strength of acrylic plastics ("Fluorax", etc.), unfavorable conditions of prosthetics in elderly patients, processes of atrophy of the alveolar process and mucous membrane. It is also necessary to note a slightly higher number of repeated visits to CI with a large volume of made dentures, compared to $\mathrm{CI}$, which produced a smaller number of dentures - by $14.45 \%$. This moment needs further study. 


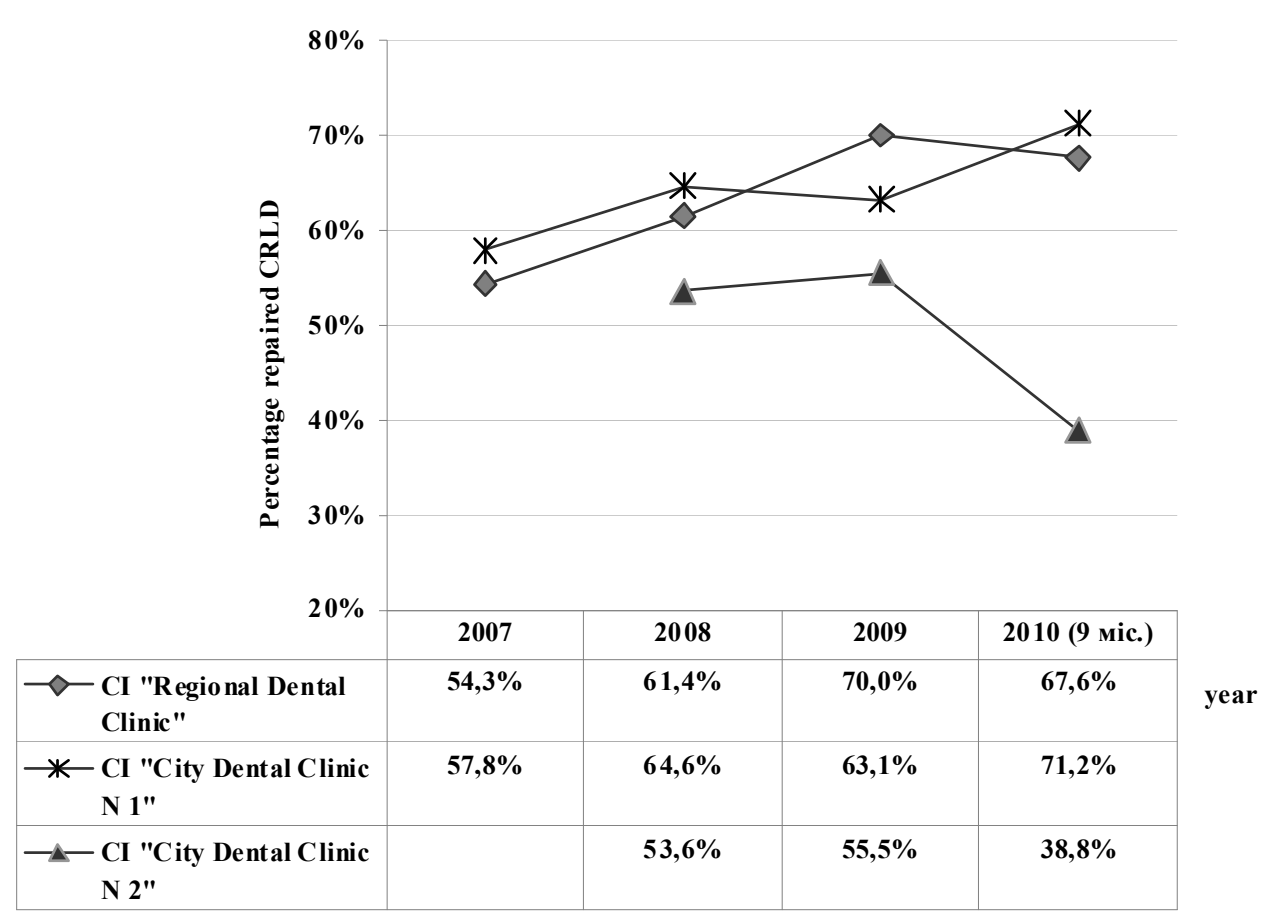

Fig. 2. Dynamics of the relative quantity (\%) of repaired CRLDs in 2007-2010 on the basis of orthopedic departments of dental institutions

The recent data of the other observation, performed on the basis of the clinic of the SE "DMA of HM of Ukraine" during 2015-2017, and their comparison with the data of the CI "City Dental Clinic N 2" from the first study, as the closest in the volume of work, indicates statistically insignificant differences in the number of repairs of CRLDs of the upper jaw. This can be explained by the fact that, despite the use of more advanced materials and methods for the manufacture of the bases of CRLD, the problem of improving quality of their manufacturing and increasing their strength is not fully resolved. The study of the problem of correlation between the number of manufactured and repaired dentures gives us the opportunity to state that, despite a slight decrease in the ratio of the number of originally made dentures to repaired ones, this percentage remains rather high. It should be noted that indirect prosthesis rebase and repair are half-measures that do not affect the causes of this prosthesis failure. Accordingly, unnecessary waste time of the doctor and dental technician, additional costs of materials and material loss confirm the need for using methods of strengthening acrylic basis of the CRLD to identify the causes leading to the destruction of the denture bases, and the technique we propose to prosthetics is one of the ways of dealing with.

\section{The total number of manufactured and repaired CRLD in 2015-2017 on the basis of the clinic of SE "DMA"}

\begin{tabular}{l|c|c|c|c}
\hline \multirow{2}{*}{ Index } & \multicolumn{3}{|c|}{ Year of study } & \multirow{2}{*}{ Mean, M \pm m } \\
\cline { 2 - 4 } & 2015 & 2016 & 2017 & \\
\hline Number of CRLD, abs. & 173 & 156 & 211 & $180.0 \pm 16.3$ \\
Number of repair of CRLD, abs. & 82 & 77 & 102 & $87.0 \pm 7.6$ \\
Number of repair of CRLD, $\%$ & 47.4 & 49.4 & 48.3 & $48.4 \pm 0.6$ \\
\hline
\end{tabular}




\section{CONCLUSIONS}

1. More than $50 \%$ of patients who received orthopedic treatment with full removable dentures on the upper jaw sought for the dentist to fix the prosthesis over a three-year follow-up period.

2. During the second observation and comparison of the indices with the data of the pre- vious one, statistically significant differences were not revealed, which indicates the relevance of finding ways to strengthen CRLD basis and reduce the number of secondary visits to dental clinics.

\section{REFERENCES}

1. Alter YM, Ogorodnikov MY. [Removable dentures with polyurethane basis: studies. manual for dentists, orthopedic and dental technicians]. Moskva. 2009;25. Russian.

2. Vasilenko RE. [Statistical analysis of the operational period of use of full removable prostheses in the industrial region]. Visnyk stomatolohii. 2012;1:92-93. Russian.

3. Vatamaniuk MM, Bielikov OB, Maksymiv OO. [Complete loss of teeth. Prevalence. Need for ortho- pedic treatment]. Bukovynskyi medychnyi visnyk. 2012;16,4(64):191-5. Ukrainian.

4. Labunec VA. [The need, security and need of the adult population of Ukraine in dental orthopedic care]. Visnyk stomatolohii. 2000;1:48-49. Russian.

5. Pysarenko OA, Tsvietkova NV, Kuznietsov VV. [Localization of breakdowns of bases of complete removable dentures of upper jaw and number of lesions]. Stomatologicheskaya nauka i praktika. 2015;6(11):19-23. Ukrainian.

\section{СПИСОК ЛІТЕРАТУРИ}

1. Альтер Ю. М., Огородников М. Ю. Съемные зубные протезы с базисом из полиуретана: учеб. пособие для врачей стоматологов-ортопедов и зубных техников. Москва, 2009. 25 с.

2. Василенко Р. Е. Статистический анализ эксплуатационного периода пользования полными съемными протезами в промышленном регионе. Вісник стоматологї̈. 2012. № 1. С. 92-93.

3. Ватаманюк М. М., Бєліков О. Б., Максимів О. О. Повна втрата зубів. Поширеність. Потреба в ортопедичному лікуванні. Буковин. мед. вісник. 2012. T. 16, № 4(64). C. 191-195.

4. Лабунец В. А. Потребность, обеспеченность и нуждаемость взрослого населения Украины в стоматологической ортопедической помощи. Вісник стоматології. 2000. № 1. С. 48-49.

5. Писаренко О. А., Цвєткова Н. В., Кузнєцов В. В. Локалізація поломок базисів повних знімних протезів верхньої щелепи і кількість лагоджень. Стоматолог. наука и практика. 2015. № 6 (11). С. 19-23. 